\title{
The Effect of Short Stature on Children's Cognitive Abilities and Psychosocial Condition
}

\author{
Heni Hastuti, Zahra Dzakiyatin Nisa, Husnia Auliyatul Umma, \\ Anak Agung Alit Kirti Estuti Narendra Putri, Yusuf Ari Mashuri
}

Faculty of Medicine, Universitas Sebelas Maret

\section{ABSTRACT}

Background: Children are categorized as short stature when the Height for Age results are below the 3rd percentile of CDC growth chart standard. Short stature on children will have an impact on increased mortality and morbidity, children's cognitive development, and psychological abilities. This study aims to investigate the effect of short stature on cognitive abilities and psychosocial condition of primary school children.

Subjects and Method: A cross-sectional study was conducted at Pasar Kliwon 01 Primary School, Surakarta, Central Java, Indonesia. A total of 81 students from 3 rd $-5^{\text {th }}$ grades of were selected by consecutive sampling. The dependent variables were cognitive ability and psychosocial condition. The independent variable was body height. Body height was measured by microtoise. Cognitive ability was assessed based on mathematics, Indonesian language, and natural sciences score. PsychoCite this as:

Hastuti H, Nisa ZD, Umma HA, Putri AAKEN, Mashuri YA (2020). The Effect of Short Stature on Children's Cognitive Abilities and Psychosocial Condition. J Matern Child Health. 05(03): 297-303. https://doi.org/10.26911/thejmch.2020.05.03.08.

cc) (1) Journal of Maternal and Child Health is licensed under a Creative Commons Attribution-NonCommercial-ShareAlike 4.o International License. social condition was assessed using Pediatric Symptom Checklist-17. The data were analyzed by a multiple logistic regression.

Results: Short stature increased cognitive ability $(\mathrm{OR}=2.86 ; 95 \% \mathrm{CI}=1.03$ to $7.92 ; \mathrm{p}=$ 0.043), and it was statistically significant. Short stature increased psychosocial condition, $(\mathrm{OR}=$ 2.24; $95 \% \mathrm{CI}=0.51$ to $9.70 ; \mathrm{p}=0.279$ ), but it was statistically non-significant.

Conclusion: Short stature increases cognitive ability and psychosocial condition.

Keywords: short stature, cognitive ability, psychosocial condition

\section{Correspondence:}

Heni Hastuti. Faculty of Medicine, Universitas Sebelas Maret. Jl Ir. Sutami 36A, Surakarta Central Java, Indonesia. Email: henihastuti.1988@gmail.com. Mobile: 081904534310.

\section{BACKGROUND}

Human growth and development is a physiological process. The process starting from intrauterine and accelerating during childhood (Barstow and Rerucha, 2015). The process of growth in children is a process that can be measured. Linear growth is the most accurate growth indicator (Foote, 2012). The linear growth speed is one of the biomarker of children's health status, congenital, and environmental factors (Kelly et al., 2014) Linear growth rates can be measured using anthropometric measurements.
Nutritional status based on the Height/Age index can show an indication of chronic nutritional problems (Riskesdas, 2013).

Children are included in the category of short stature when the Height/Age Zscore is below -2 SD percentile according to WHO or below the $3^{\text {rd }}$ percentile according to $\mathrm{CDC}$ (WHO, 2018). The short stature category indicates a growth failure that is closely related to a decrease in productivity and short stature in adulthood (Salimar, 2013). 
In 2013, around 161 million children in the world had Height/Age below - 2 SD percentile according to WHO (Onis and Branca, 2016). Based on National Basic Health Research (Riskesdas) in 2013 there were as many as $30.7 \%$ of Indonesian children aged 5-12 years included in the short stature category (12.3\%: very short and 18.4\%: short). This number increased from 2010 (25.6\%). The prevalence of short stature in children aged 5-12 years in Central Java Province is $28.6 \%$ (Kemenkes, 2013) The high number of stunting/short stature in children will have an impact on increasing mortality, morbidity and disruption in children's cognitive development (Onis and Branca, 2016).

A study conducted by Venables and Raine (2016), showed that the Z-score of Height/Age has a positive correlation with a child's IQ score. A study in Cambodia in 2014 showed that cognitive abilities below the average for school-aged children in Cambodia were closely related to chronic nutritional deficiencies and recent nutritional status (iron status) (Perignon et al., 2014).

Another study conducted in Ethiopia in 2015 concluded that stunting, anemia, and selenium deficiency are closely related to poor cognitive performance (Gashu et al., 2016). A similar study carried out in the slums of Jakarta in 2016 showed that short stature was related to the children's low level of achievement in school (Arfines and Puspitassari, 2017).

A study conducted by Walker et al in 2015 indicated that children with short stature tend to have worse emotional and behavioral abilities (Walker et al., 2015). A similar study conducted in suburban areas in Indonesia showed that adolescents with stunting/short stature had a higher tendency to have psychosocial disorders than adolescents with normal height (Erfanti et al., 2016).

Many researchers have conducted research on the relationship of stunting to children's cognitive abilities. However, there are few studies that analyzed the effect of short stature on children on cognitive abilities and psychosocial condition of primary school children. Therefore, this study aimed to investigate the effect of short stature on cognitive abilities and psychosocial condition of children in the primary school in Surakarta.

\section{SUBJECTS AND METHOD}

\section{Study Design}

This was A cross-sectional study conducted at Pasar Kliwon 01 Primary School, Surakarta, Central Java, in October 2018.

\section{Population and Sample}

A total of 81 students from $3^{\text {rd }}, 4^{\text {th }}$, and $5^{\text {th }}$ grades was included as a sample and selected by consecutive sampling.

\section{Study Variables}

The dependent variables were cognitive abilities and psychosocial condition. The independent variable was children body height.

\section{Operational Definition of Variables} Body height of child was classified as short based on height according to age indicator based on the CDC standard Height/ Age curve. Children were classified in the category of short stature if the height $<3^{\text {rd }}$ percentile SD CDC. The height/age was a categorical variable and categorized as short and normal stature.

Age was measured as continous scales, but it was transformed into dichotomous, categorized as under 11 years and above 11 years.

Sex was measured as categorical scales, categorized as female and male.

Socioeconomic status was measured as continous scales, but it was transformed 
into dichotomous, categorized as uppermiddle and lower-middle socioeconomic status.

Cognitive ability was the children's cognitive abilities at school, with a categorical scale.

Table 1. Converted Score based on 2013 Indonesian Curriculum

\begin{tabular}{cc}
\hline Scale o-100 & Mark \\
\hline $86-100$ & $\mathrm{~A}$ \\
$81-85$ & $\mathrm{~A}-$ \\
$76-80$ & $\mathrm{~B}+$ \\
$71-75$ & $\mathrm{~B}$ \\
$66-70$ & $\mathrm{~B}-$ \\
$61-65$ & $\mathrm{C}+$ \\
$56-60$ & $\mathrm{C}$ \\
$51-55$ & $\mathrm{C}-$ \\
$46-50$ & $\mathrm{D}+$ \\
$0-45$ & $\mathrm{D}$ \\
\hline
\end{tabular}

(Permendikbud, 2013)

Psychosocial condition was children's psychosocial condition at school, categorized as normal and not normal.

Tabel 2 Cut-off score PSC-17

\begin{tabular}{lc}
\hline & Cut off Score \\
\hline Total Score & 15 \\
Attention Subscale & 7 \\
Externalizing Subscale & 7 \\
Internalizing Subscale & 5 \\
\hline
\end{tabular}

(IDAI, 2013)

\section{Study Instruments}

Body height was measured using microtoise, cognitive abilities were examined using last semester's learning score (mathematics, sciences, and Indonesian Language). The psychosocial condition was assessed using the PSC-17 questionnaire (Pediatric Symptom Checklist-17).

\section{Data Analysis}

The data were analyzed by a multiple logistic regression.

\section{Research Ethic}

The ethical clearance was obtained from the Faculty of Medicine Universitas Sebelas Maret's ethical committee. The informed consent was obtained from student's parents. Sample confidentiality was kept during data analysis.

\section{RESULTS}

1. Sample Characteristics

$56.7 \%$ of the respondents were female. The majority of the respondents had a normal height (61.7\%). However, 31 (38.3\%) students were categorized as short stature. Most of them had normal psychosocial condition (87.6\%). Most of the students had $\mathrm{B}+$ rapport score.

Table 3. Sample Characteristics (Categorical Data)

\begin{tabular}{lcc}
\hline \multicolumn{1}{c}{ Variables } & n & \% \\
\hline Body height & & \\
Normal & 50 & 61.73 \\
Short & 31 & 38.27 \\
Sex & & \\
Male & 35 & 43.21 \\
Female & 46 & 56.79 \\
Academic Score & & \\
A & 10 & 12.35 \\
A- & 22 & 27.16 \\
B & 31 & 38.27 \\
B & 18 & 22.22 \\
Psychosocial Condition & & \\
Normal & 71 & 87.65 \\
Abnormal & 10 & 12.35 \\
\hline
\end{tabular}


Hastuti et al./ Short Stature, Cognitive Abilities, and Psychosocial Condition

Table 4. The Results of Bivariate Analysis of Relationships between Child's Body Height on the Cognitive Ability and Psychosocial Condition

\begin{tabular}{lcc}
\hline \multicolumn{1}{c}{ Dependent Variables } & $\mathbf{r}$ & p \\
\hline Cognitive abilities & 0.22 & 0.047 \\
Psychosocial condition & 0.24 & 0.027 \\
\hline
\end{tabular}

\section{Bivariate analysis}

There was a positive and significant correlation between body height and cognitive abilities $(\mathrm{r}=0.22 ; \mathrm{p}=0.047)$. There was a positive and significant correlation between body height and psychosocial condition ( $\mathrm{r}=$ $0.24 ; p=0.027$ ).

Table 5. The results of multiple logistic regression on the effects of sex, age, and socioeconomic on cognitive abilities

\begin{tabular}{lcccc}
\hline \multirow{2}{*}{ Independent Variables } & \multirow{2}{*}{ OR } & \multicolumn{2}{c}{$\mathbf{9 5 \%}$ CI } & \multirow{2}{*}{ p } \\
\cline { 3 - 4 } Sex & 2.57 & Lower limit & Upper limit & \\
Age & 1.80 & 0.96 & 6.84 & 0.058 \\
Short stature & 2.86 & 1.03 & 4.75 & 0.233 \\
Socioeconomic & 0.63 & 0.03 & 7.92 & 0.043 \\
\hline
\end{tabular}

\section{Multivariate analysis}

Tabel 5 showed the results of multiple logistic regression analysis on the effects of sex, age, and socioeconomic on cognitive abilities. Table 5 showed that sex increased cognitive ability $(\mathrm{OR}=2.57 ; 95 \% \mathrm{CI}=0.96$ to $6.84 ; \mathrm{p}=0.058)$, and it was marginally significant.

Table 5 showed that age increased cognitive ability $(\mathrm{OR}=1.80 ; 95 \% \mathrm{CI}=0.68$ to $4.75 ; \mathrm{p}=0.233$ ), but it was statistically non-significant.

Table 5 showed that short stature increased cognitive ability and it was statistically significant $(\mathrm{OR}=2.86 ; 95 \% \mathrm{CI}=$ 1.03 to $7.92 ; \mathrm{p}=0.043$ ).

Table 5 showed that socioeconomic decreased cognitive ability $(\mathrm{OR}=0.63 ; 95 \%$ $\mathrm{CI}=0.03$ to $12.9 ; \mathrm{p}=0.767$ ), but it was statistically non-significant.

Table 6. The results of multiple logistic regression on the effects of sex, age, and socioeconomic on psychosocial condition

\begin{tabular}{lcccc}
\hline \multirow{2}{*}{ Independent Variables } & \multirow{2}{*}{ OR } & \multicolumn{2}{c}{ 95\% CI } & \multirow{2}{*}{ p } \\
\cline { 3 - 4 } & & Lower limit & Upper limit & 0.913 \\
Sex & 1.08 & 0.26 & 4.38 & 0.264 \\
Age & 2.68 & 0.47 & 15.2 & 0.279 \\
Short stature & 2.24 & 0.51 & 9.70 & 0.138 \\
Socioeconomic condition & 9.71 & 0.48 & 195.6 & \\
\hline
\end{tabular}

Tabel 6 showed the results of multiple logistic regression analysis on the effects of sex, age, and socioeconomic on psychosocial condition. Tabel 6 showed that there was no different of sex on psychosocial condition $(\mathrm{OR}=1.08$; $95 \% \mathrm{CI}=0.26$ to 4.38 ; $\mathrm{p}=0.913)$.

Table 6 showed that short stature increased psychosocial condition, but it was statistically non-significant $(\mathrm{OR}=2.24 ; 95 \%$ $\mathrm{CI}=0.51$ to $9.70 ; \mathrm{p}=0.279$ ).

Table 6 showed that age $(\mathrm{OR}=2.68$; $95 \% \mathrm{CI}=0.47$ to $15.2 ; \mathrm{p}=0.264)$ and socioeconomic $(\mathrm{OR}=9.71 ; 95 \% \mathrm{CI}=0.48$ to 195.6; $\mathrm{p}=$ 0.138) increased psychosocial condition, but they were statistically nonsignificant. 


\section{DISCUSSION}

The results of a multiple logistic regression showed that there was no significant effect of sex, age, and socioeconomic condition on cognitive abilities and psychosocial condition.

This study's results are in accordance with the theory presented by Venables and Raine (2016) cognitive activities including memory ability, perception, attention, and depiction are closely related to the local efficiency index of the cortical area located in the parietal, temporal, occipital, frontal lobe, and subcortical regions of the thalamus, amygdala and hippocampus (Venables and Raine, 2016).

Human intellectual performance is related to the integrity of the white matter in the genu callosum, corpus callosum (splenium), cingulum, and superior longitudinal fasciculus (Chiang et al., 2012). Luders in his study reported that there was a positive correlation between IQ (cognitive ability) and the thickness of the corpus callosum, myelination of neurons along the corpus callosum would improve the smooth transfer of intermittent information which causes a person to process information quicker (Luders et al., 2009).

Short stature in children is an implication of the chronic malnutrition process. Prolonged nutritional deficiencies will have an impact on neuronal proliferation disorders, axon and dendrite growth, synapse formation, myelinated disorders, and can cause apoptosis of brain neurons. Studies conducted in humans showed that children with malnutrition experienced a reduction in the volume of the frontal and prefrontal cortex compared to the control population. Autopsy results in infants with chronic protein malnutrition indicate a decrease in dendritic arborization (new dendritic synaptic branch formation) (Rosene et al., 2004).
A study conducted on rats showed that malnutrition that occurs during the pre-natal and post-natal period will reduce the number of nerve synapses and decrease myelination in brain neurons so that information transmission tends to run slower and can be seen from lower cognitive abilities (IQ) compared to normal children his age (Wiggins et al., 1984).

Malnutrition that occurs in children will have an impact on the neurocognitive function of the brain and tends to predispose to externalizing disorders in children. Externalizing disorders that occur are closely related to the low IQ of children with short stature. Chronic malnutrition causes disruption of brain growth and development and increases the predisposition of antisocial attitudes in children. The disorder that occurs is mainly related to the orbital prefrontal cortex and the ventral cortex media which play a role in regulation of emotions and inhibition of aggressive behavior. Lesions in the prefrontal cortex during childhood will manifest as disinhibition of antisocial and anti-aggressive behavior in later life (Liu et al., 2014). The reduction of white matter mass in the prefrontal cortex is associated with antisocial personality disorder and aggressive behavior (Andri and Kusumawardhani, 2007).

This study has several strengths. First, the psychosocial condition was measured with the PSC-17 questionnaire. This questionnaire was valid and reliable tools to measure children's psychosocial condition. Second, this study also included several variables, such as sex, age, and parent's socioeconomic condition, thus reduce the bias. However, there are also limitations in this study. First, the sample size is relatively low. This can result in low generalization impact of the study result. Second, the study was conducted in one school. Thus, 
the variation of parent's socioeconomic conditions is also low.

There was an effect of short stature on cognitive abilities and psychosocial condition of children in primary school. Children with short stature tend to have cognitive abilities and lower psychosocial condition compared to children of normal height. Screening and comprehensive management of short stature are needed to minimize the negative effect.

AUTHOR CONTRIBUTION
Heni Hastuti, Zahra Dzakiyatin Nisa,
Husnia Auliyatul Umma, Anak Agung Alit Kirti Estuti Narendra Putri, and Yusuf Ari Mashuri collected the data, measured body height, measured cognitive ability, measure psychosocial condition, did data analysis, and wrote the paper.

\section{CONFLICT OF INTEREST}

There are no conflicts of interest.

FUNDING AND SPONSORSHIP

There was no external funding.

\section{ACKNOWLEDGEMENT}

The authors gratefully acknowledge Pasar Kliwon 01 Primary School for giving permission to conduct the research in the school.

\section{REFERENCE}

Andri A, Kusumawardhani (2007). The neurobiology of borderline personality disorder: biological approach in impulsive and aggressive behavior. Majalah Kedokteran Indonesia. 57(4): 123-128.

Arfines PP, Puspitasari FD (2017). Hubungan stunting dengan prestasi belajar anak sekolah dasar di daerah kumuh, kotamadya Jakarta Pusat. Buletin Penelitian Kesehatan, 45(1): 45-52. http://dx.doi.org/10.22435/bpk.v45i1.5798.45-52

Barstow C, Rerucha C (2015). Evaluation of short and tall stature in children. Am Fam Physician. 92(1): 43-50. https://www.aafp.org/afp/2015/0701/p43.pd f.

Chiang MC, Barysheva M, McMahon KL, de Zubicaray GI, Johnson K, Montgomery GW, Martin NG, et al. (2012). Gene network effects on brain microstructure and intellectual performance identified in 472 twins. J. Neurosci. 32(25): 8732-8745. https://doi.org/10.1523/JNEUROSCI.5993-11.2012

de Onis MD, Branca F (2016). Childhood stunting: A global perspective. Matern Child Nutr. 12: 12-26. https://doi.org/10.1111/mcn.12231.

Erfanti D, Setiabudi D, Rusmil K (2016). The relationship of psychosocial disfunction and stunting of adolescents in suburban, Indonesia. J Med Psychol, 5(4): 57-65. http://dx.doi.org/10.4236/ojmp.2016.54007.

Foote JM (2014). Optimizing linear growth measurement in children. $\mathrm{J}$ Pediatr Health Care. 28 (5): 413-419. https://doi.org/10.1016/j.pedhc.2014.01.001

Gashu D, Stoecker BJ, Adish A, Haki GD, Bougama K, Marquis GS (2016). Ethiopian pre-school children consuming a predominantly unrefined plantbased diet have low prevalence of iron-deficienci anaemia. Public $\mathrm{He}-$ alth Nutr, 19(10): 1834-1841. https://doi.org/10.1017/S13689800150036 26.

Ikatan Dokter Anak Indonesia (IDAI) (2013). Skrining gangguan perilaku remaja dengan menggunakan Pediatric Symptom Checklist (PSC). https://dokumen.tips/documents/skrininggangguan-perilaku-remaja-dengan- 
Hastuti et al./ Short Stature, Cognitive Abilities, and Psychosocial Condition

kuesioner-psc-17.html. Diakses Agustus 2018.

Kelly A, Winer KK, Kalkwarf H, Oberfield SE, Lappe J, Gilsanz V, Zemel BS (2014). Age based reference ranges for annual height velocity in US children. J Clin Endocrinol Metab, 99(6): 21042112. https://doi.org/10.1210/jc.2013-4455.

Kemenkes (2013). Riset Kesehatan Dasar. Badan Penelitian dan Pengembangan Kesehatan Kementrian Kesehatan Republik Indonesia. http://www.depkes.go.id/resources/download/genera 1/Hasil\%20Riskesdas\%202013.pdfDiakses pada April 2018.

Liu H, Liao J, Jiang W, Wang W (2014). Changes in low-frequency fluctuations in patients with antisocial personality disorder revealed by resting-state functional MRI. PloS ONE, 9(3): e8979o. https://doi.org/10.1371/journal.pone.0089790.

Luders E, Narr KL, Thompson PM, Toga AW (2009). Neuroanatomical correlates of intelligence. Intelligence 37(2): 156-163. https://doi.org/10.1016/j.intell.2008.07.002

Perignon M, Fiorentino M, Kuong K, Burja K, Parker M, Sisokhom S, Chamnan C, Berger J, Wieringa FT (2014). Stunting, poor iron status and parasite infection are significant risk factors for lower cognitive performance in Cambodian school-aged children. PloS ONE, 9(11): e112605. https://doi.org/10.1371/journal.pone.011260 5 .

Permendikbud RI (2014). Peraturan menteri pendidikan dan kebudayaan republik indonesia nomor 104 tahun 2014: Penilaian hasil belajar oleh pendidik pada pendidikan dasar dan pendidikan menengah.
Rosene DL, Lister JP, Schwagerl AL, Tonkiss J, McCormick CM, Galler JR (2004). Prenatal protein malnutrition in rats alters the c-Fos response of neurons in the anterior cingulate and medial prefrontal Region to behavioral stress. Nutr Neurosci. 7(5-6): 281289. https://doi.org/10.1080/10284150400015573.

Salimar, Kartono D, Fuada N, Setyawati B (2013). Stunting anak usia sekolah di Indonesia menurut karakteristik keluarga. Penelitian Gizi dan Makanan, 36 (2): 121-126. https://media.neliti.com/media/publications/223527stunting-anak-usia-sekolah-di-indonesia.pdf.

Venables R, Raine A (2016). The impact of malnutrition on intelligence at 3 and 11 years of age: The mediating role of temperament. Dev Psychol. 52(2): 205-20. https://doi.org/10.1037/dev0000046.

Walker SP, Chang SM, Powell C, Simonoff E, Grantham-McGregor SM (2007). Early childhood stunting is associated with poor psycological functioning in late adolescence and effects are reduced by psychosocial stimulation. J Nutr, 137(11): 2464-2469. https://doi.org/10.1093/jn/137.11.2464

Wiggins RC, Fuller GN, Brizzee L, Bissel AC, Samorajski T (1984). Myelination of the rat optic nerve during postnatal undernourishment and recovery: a morphometric analysis. Brain Res. 308(2): 263-272. https://doi.org/10.1016/ooo6-8993(84)91065-5

World Health Organization (WHO) (2018). Child growth standards. Available at: https://www.who.int/childgrowth/en /. 